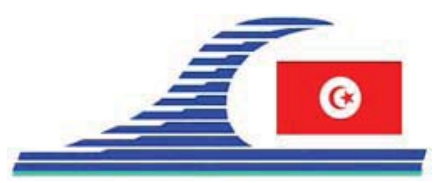

Conférence Méditerranéenne Côtière et Maritime EDITION 1, HAMMAMET, TUNISIE (2009)

Coastal and Maritime Mediterranean Conference

Disponible en ligne - http://www.paralia.fr - Available online

\title{
Development of marina-networks: a useful tool for coastal, ecological and sustainable planning of nautical tourism
}

\author{
Heiner HAASS 1
}

1. Deutsche Marina Consult, Am Weissdorn 13, D-30459 Hannover, Germany. http://www.d-marina-consult.de

zentrale@d-marina-consult.de

\begin{abstract}
:
The development of nautical tourism is an important coastal and economic factor for the Mediterranean countries. If the north of the Mediterranean Sea is well developed, the south coast part has a high potential for development of nautical tourism. For a sustainable development considering the coastline protection, the economic and the ecology topics, the networks of marinas are necessary.

This planning by regional development gives a benefit for many communities and regions. The objectives of nautical tourism can be integrated in the regional development and thus, the protection of shoreline and ecosystems are guaranteed.

A tool such as a marina-network harmonizes the coastal planning and produces a network of various marina-types. In relation with the community small marinas to super yacht facilities can be established.

The paper gives some examples of how to develop a marina-network, gathers the designing/planning of various types of marinas and finally, gives design recommendations for the marina-planning.
\end{abstract}

\section{Keywords:}

Nautical tourism - Coastline protection - Economy - Ecology - Marinas - Regional development - Marina-types - Design and planning

\section{Introduction}

The northern part of the Mediterranean Sea is a traditional touristic area in Europe, with the increase of boating and yachting. Nautical tourism constitutes a source of profits for the communities. A lot of marinas were built in the sixties and also recently, in these last years. The northern part of the Mediterranean Sea is full of boats, of yachts and of super yachts. In many countries or Mediterranean areas, it is impossible to have a place in a port for berthing such as in the Balearic Islands, the Catalonian coast, Croatia coast, ... . The demand is increasing for many marinas including places for the super yacht business and facilities.

DOI: $10.5150 / \mathrm{cmcm} .2009 .050-4$ 
To face the increasing demand of yachting and boating activities in the Mediterranean Sea, two potential zones are identified, as shown in figure 1: The Black Sea and the south coast of the Mediterranean sea. Both are regions with a high tourist potential and of course, with strong economic impacts from the nautical tourism. The development has started in these regions, and in many places in the south coast, marina-projects are beginning.

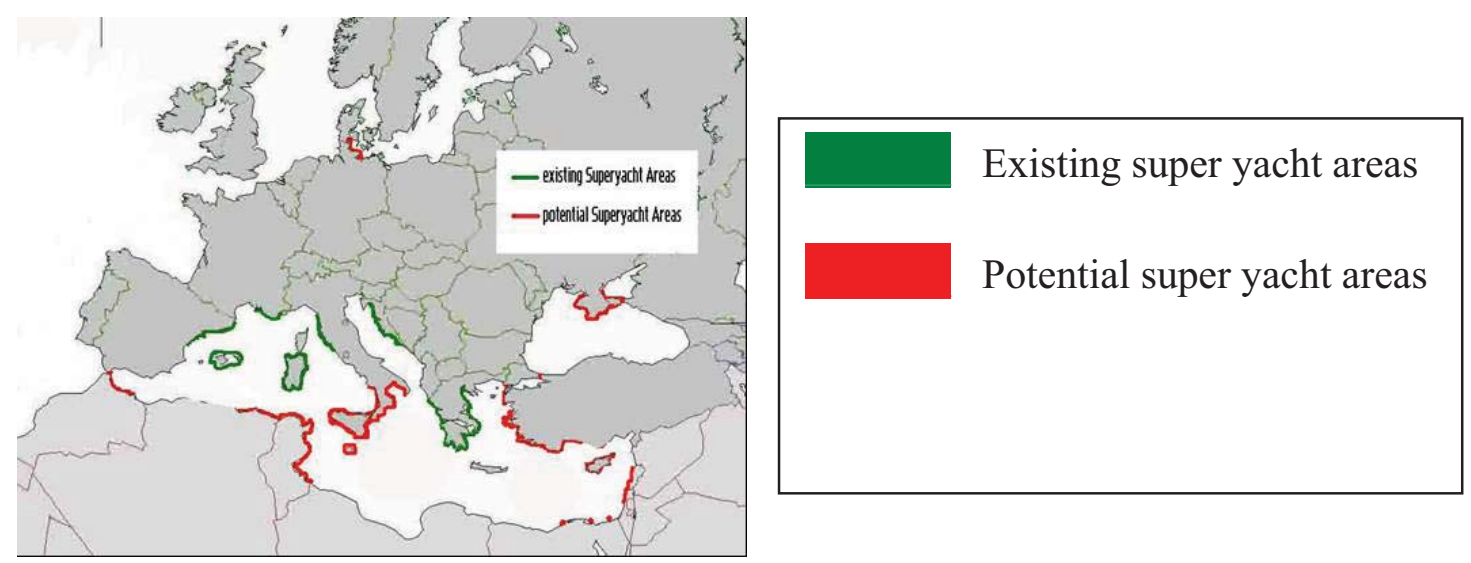

Figure 1. Location of the potential super yacht areas (HAASS, 2008).

To handle this development, it is important and necessary to work on the basis of guidelines for a sustainable development. Thus, it is necessary to give guidelines for the regional development of marina-projects and to plan marina-networks to harmonize the coastline development.

\section{Marina-network planning}

The marina-network planning is a useful tool to guarantee the regional distribution of marinas along the coastline. The negative effects of marina concentration can be reduced or solved by a marina-network. So, the attractiveness of the regional nautical tourism can be increased and many communities can profit from the marina-network. It is also possible to take into account the ecological and economical aspects.

The marina-network planning is a useful tool for regional planning. It results in guarantees for the right locations of marinas and their operations.

The marina-network concerns various sizes and types of marinas depending on the local possibilities and situations. For the yachting business it is interesting to find various marina-types along the available coastline.

It is very important to develop the marina-network in relation to the regional communities and the proposed facilities. So, the size and the type of a marina must be harmonized with the community. Considering the historic and traditional heritage is a basis for nautical tourism and constitutes an important data for the marina-network. 
And finally, it is taking into account the ecological situation. For a sustainable tourism, the ecological quality of the coastline is very important. The sustainability of the marinas is an economic factor. The yachting business has a long and sustainable life if various marinas works are developed together and in harmony. So, the marina-network is to be planned by a categorization of existing situations. Most of the time, three categories are enough. Moreover, it is necessary to find the right locations for new marinas together with their sizes and specific types. The distances between the marinas must be adjusted for different boats and yachts moving by sailing or by motor.

The proposed network must be discussed with the government and the communities, with the harbor authorities and others. The benefits of a marina-network plan are conducted for the regional development and for coastline planning and nautical tourism.

\section{The marina design and planning}

On the basis of the marina-network plan, it is possible to develop specific marina projects. With the guidelines and rules of the network plan, it is easy to plan the various projects, to find investors and financers and to organize the projects inside the communities. Many projects can be started early, while doing the networking.

The design of a marina must be considered as an architectural construction for touristic uses. The functional and aesthetic aspects are essential. A marina is not only a "parking for the boats", social aspects must be considered. It is also the representative image factor for the community and its region.

A marina must be divided into different functional zones. This is the basis for designing and managing, especially with what regards risks and safety. The design of a marina consists in the waterside and the landside. Both parts must constitute an architectural unit with the same design. As indicated in figure 2, the waterside area represents nearly $60 \%$ and the landside $40 \%$ of the total of the marina area.

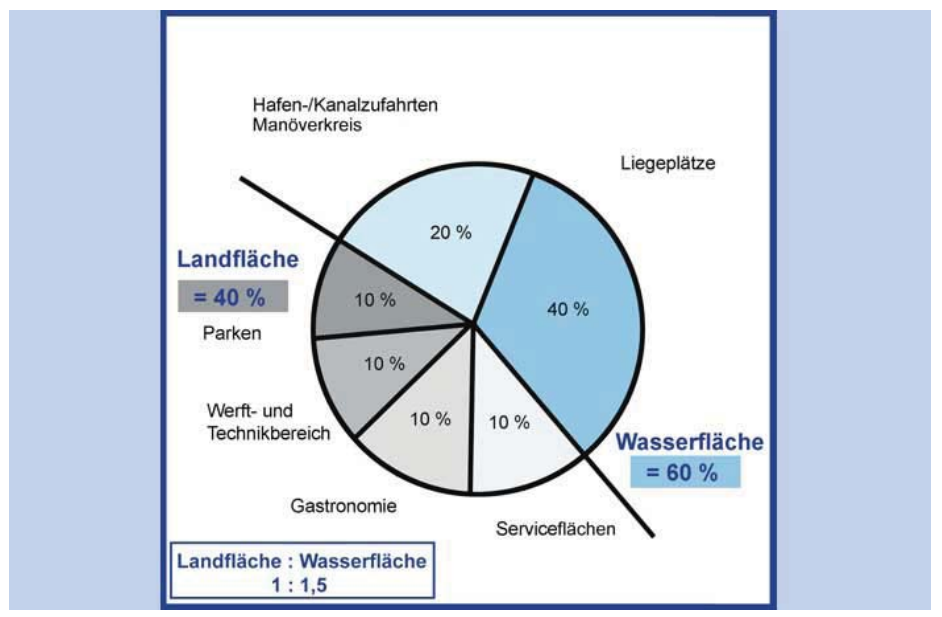

Figure 2. Marina zoning (HAASS, 2003) 


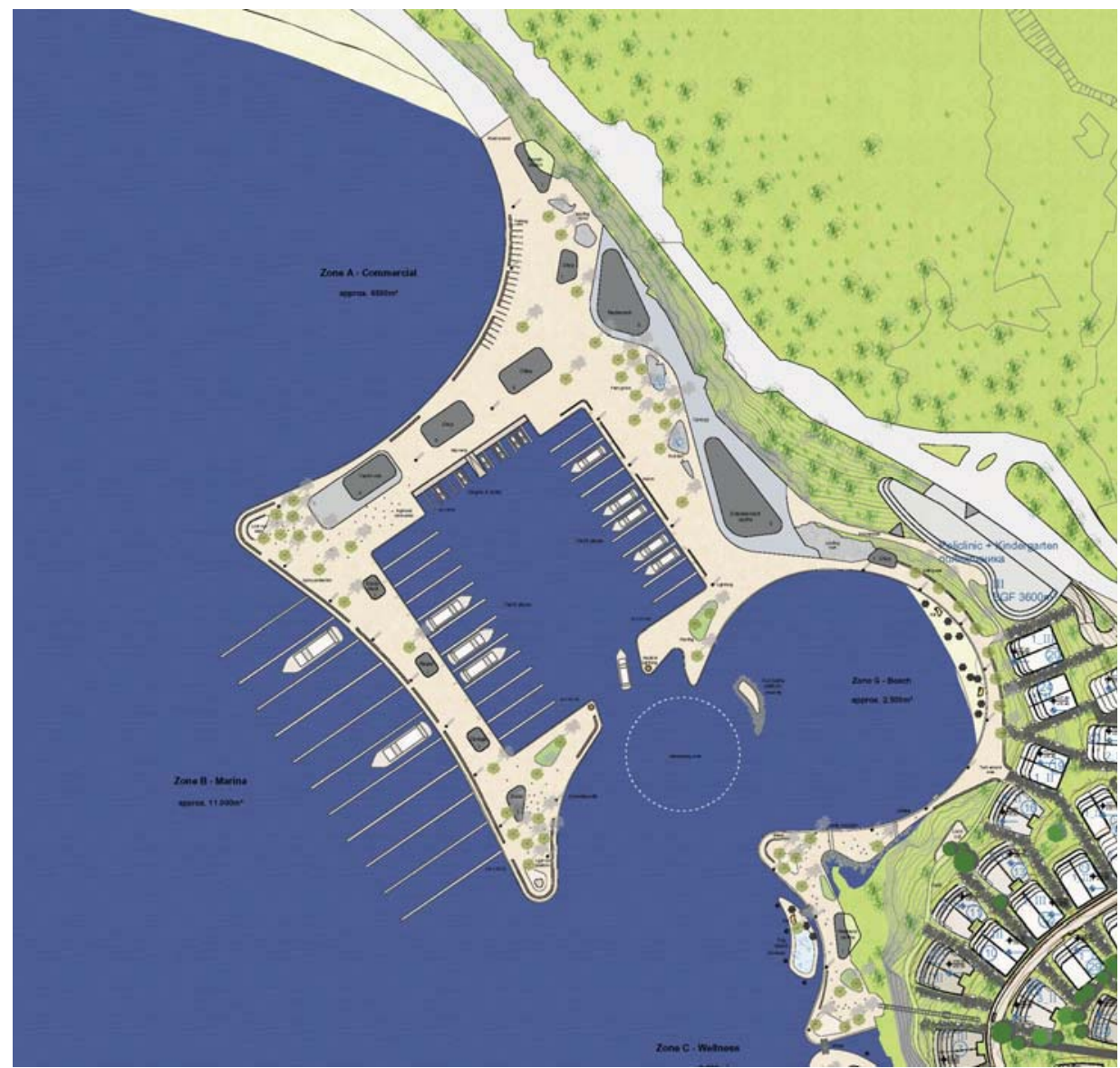

Figure 3. Example of Budva marina in Montenegro (DMC, web site).

The marina should be divided into a technical zone (fuel, waste disposal, repair/wharf, ...), in a berthing area (pontoons, jetties, slips...), in a public area (promenade, restaurants, shops, green areas,) and in a parking area (cars, trailers, storages ...). This concept of planning is the basis for design, construction and risk management.

\section{Conclusion}

It is possible to develop marina-networks along a coastline in harmony with environment, for a sustainable regional development. This type of marinas is optimized for management and maintenance and is an optimal factor for the touristic image of a region/community.

\section{References}

DMC -Deutsche Marina Consult- (web site). http://www.d-marina-consult.de

HAASS H. (2003). Planungshandbuch für Sportboothäfen und Marinas. Edition bnb, ISBN 3-9807842-4-X, Bremen, Germany.

HAASS H. (2008). Superyacht-marinas as an element for a sustainable, environmental and urban development. PIANC Mediterranean Days, Palermo, Italy. 